\begin{tabular}{|l|l|l||}
\hline \multicolumn{2}{|c|}{ PublisherInfo } \\
\hline \hline PublisherName & $:$ & BioMed Central \\
\hline \hline PublisherLocation & $:$ & London \\
\hline \hline PublisherImprintName & $:$ & BioMed Central \\
\hline \hline
\end{tabular}

\title{
Molecular make-up of a malaria mosquito
}

\begin{tabular}{|l|l|l||}
\hline \multicolumn{2}{|c|}{ ArticleInfo } \\
\hline \hline ArticleID & $:$ & 4597 \\
\hline \hline ArticleDOI & $:$ & $10.1186 /$ gb-spotlight-20021003-02 \\
\hline \hline ArticleCitationID & $:$ & spotlight-20021003-02 \\
\hline \hline ArticleSequenceNumber & $:$ & 263 \\
\hline \hline ArticleCategory & $:$ & Research news \\
\hline ArticleFirstPage & $:$ & 1 \\
\hline \hline ArticleLastPage & $:$ & 3 \\
\hline \hline & & RegistrationDate : 2002-10-3 \\
\hline ArticleHistory & $:$ & OnlineDate \\
\hline \hline ArticleCopyright & $:$ & BioMed Central Ltd2002-10-3 \\
\hline \hline ArticleGrants & $:$ & \\
\hline \hline ArticleContext & $:$ & 130593311 \\
\hline \hline
\end{tabular}




\section{Jonathan B Weitzman}

Email: jonathanweitzman@hotmail.com

In the October 4 Science, a large international team of scientists lead by Robert Holt and colleagues at Celera Genomics reports the genome sequence of the mosquito Anopheles gambiae (Science, 298:129-149, October 4, 2002). The authors introduce their chosen beast as the 'scourge of humanity', delivering malaria, dengue and yellow fever to hundreds of millions of sufferers each year.

Holt et al. chose the A. gambiae PEST strain because it has been extensively studied and bacterial artificial chromosome (BAC) libraries had been previously created and mapped. They created new BAC and plasmid libraries and generated tenfold shotgun sequence coverage of the 278 megabase genome, assembling the sequence into almost 9,000 scaffolds, the longest of which was $23.1 \mathrm{Mb}$. They experienced difficulties with assembly due to the unprecedented extent of genetic variation in the PEST genome. The genome seems to contain two haplotypes of roughly equal abundance probably reflecting the outbred nature of the PEST strain. A single nucleotide polymorphism (SNP) pipeline identified about 445,000 SNPs in the Anopheles genome that are very unevenly distributed along the chromosomes. A combination of the Celera and Ensembl gene annotation programs resulted in 15,189 predicted genes. There are about 40 different types of transposons or related dispersed repeats in the $A$. gambiae genome with transposable elements comprising more than $60 \%$ of the heterochromatic component.

Comparative analysis revealed considerable similarities between the Anopheles and Drosophila genomes. Several classes of genes were similarly represented in both genomes, for example, serine proteases that are important for innate immunity and proteolysis while some gene families are expanded in the Anopheles genome, such as those encoding cell adhesion molecules. Analysis of ESTs from blood-fed mosquitoes and non-blood-fed animals, identified transcripts that are upregulated or downregulated by a blood meal.

The authors hope that study of the Anopheles genome will improve the control of malaria and other mosquito-borne diseases in the future. They predict that this goal will be achieved by reducing the number of mosquitoes (for example, by understanding the role of gene expression and genetic variation in insecticide resistance), understanding why they are attracted to human hosts (for example, by investigating the role of insect odorant receptors) and by reducing development of the malaria parasite (for example, by studying the Anopheles immune and genetic response to the parasite).

\section{References}


1. Holt RA, Subramanian GM, Halpern A, Sutton GG, Charlab R, Nusskern DR, Wincker P, Clark AG, Ribeiro JMC, Wides R, et al.: The genome sequence of the malaria mosquito Anopheles gambiae Science, 298:129-149, October 4, 2002., [http://www.sciencemag.org/cgi/content/full/298/5591/129/ DC1]

2. Celera Genomics, [http://www.celera.com]

3. The Malaria Research and Reference Reagent Resource Center, [http://www.malaria.mr4.org]

4. Anopheles gambiae genome scaffold, [http://www4.ncbi.nlm.nih.gov/projects/Malaria/ feature.html\#an_gambiae_scaffold] 